\title{
Multiple sclerosis in Australia: socioeconomic factors
}

\author{
S R Hammond, J G McLeod, P Macaskill, D R English
}

\begin{abstract}
The data from an epidemiological study on multiple sclerosis in Australia have been analysed to determine the relation between the prevalence of the disease and educational level, and the association between level of disability and employment status. There was a significantly higher frequency of multiple sclerosis in those who left school at an older age and achieved a higher educational level. The explanation of this finding remains speculative and may be related to genetic or environmental factors. The study confirmed the recognised association between moderate-severe disability and divorce-separation and lower rates of employment.
\end{abstract}

(F Neurol Neurosurg Psychiatry 1996;61:311-313)

Keywords: multiple sclerosis; Australia; socioeconomic factors

Socioeconomic factors may be related to the likelihood of developing multiple sclerosis and to its subsequent course. Studies in the United Kingdom ${ }^{1-3}$ have shown a greater prevalence of the disease in higher socioeconomic groups although this has been variable elsewhere. ${ }^{4-6}$ Because similar studies have not previously been undertaken in Australia, we analysed the data from the Australian epidemiological study of multiple sclerosis ${ }^{7-8}$ to compare the prevalence of multiple sclerosis across different socioeconomic groups as measured by level of education. The association between level of disability and marital and employment status was also examined.

\section{Methods}

The methods of case ascertainment have been fully described elsewhere. ${ }^{7-8}$ Permission was obtained for the surveyors (neurologists) to contact all patients notified to the survey in each area and they subsequently personally interviewed all these patients. Information recorded at initial assessment included age, sex, date of birth, occupation, marital status, age of school leaving, and further qualifica- tions obtained after leaving school. All patients in whom the diagnosis of multiple sclerosis was considered to be correct were then classified into clinically definite, probable, or possible groups. Laboratory results were not considered in the allocation of individual patients to particular diagnostic categories. The disability status on the prevalence day, which coincided with a national census day (30 June 1981), was assessed according to the Kurtzke disability status scale (DSS).

Excluding Victoria, a total of 2307 cases were diagnosed as clinically definite, probable, or possible on prevalence day in 1981. The distribution across states of personally examined patients was 1068 in New South Wales, 420 in Queensland, 375 in South Australia, 319 in Western Australia, and 125 in Tasmania. Victorian cases were excluded from the analyses because the survey in this state was not completed.

Prevalence rates for highest level of education (no qualifications, technical or trade certificate, diploma, university degree) and age left school $(<15,15,16,17+$ years, diploma, university degree) were age standardised for the population at the census on 30 June 1981 . Only patients with multiple sclerosis who were aged 20 years or over in 1981 were included. Age was grouped into six categories: $20-24$, 25-34, 35-44, 45-54, 55-64, and 65+ years. Poisson regression modelling ${ }^{9}$ of the prevalence rates was used to estimate the prevalence ratio, adjusted for age, of multiple sclerosis across educational categories and to test for an association. The lowest level of education was used as the reference group.

Because marital status and employment status in 1981 are likely to be affected by disease, the association between these variables and level of disability was examined. Three levels of disability were defined based on DSS score: low (0-3), moderate (4-6), and severe (7-9). The method described by Wacholder ${ }^{10}$ was used to examine the relation between level of disability and the risk of being ( $a$ ) divorced or separated for patients 25 years and over and (b) not in paid employment for patients aged 15-64 years. All models were adjusted for age (categorised into 10 year age groups with $65+$ forming the highest category for analyses of marital status) and all analyses were stratified by sex. 
Results

Of the 2307 people with multiple sclerosis, age was not known in two cases and DSS score was missing in five cases. For 2278 people aged at least 20 years with known DSS score, highest level of education was missing for 37 and age left school was missing for 50 . A total of 2160 people were aged at least 25 years and had DSS and marital status recorded. For people aged 15-64 years, 2099 had DSS and employment status recorded in 1981.

After adjusting for age, there was a significant association between highest level of education and prevalence of multiple sclerosis for both men and women (table 1). For men, the prevalence rates were similar for the two lower levels of education and also for the two higher levels; however, the rate was higher in the two upper levels compared with the other two groups. For women, the prevalence of multiple sclerosis was significantly higher for the better educated (university degree and diploma) compared with women who had no qualifications; however, the age adjusted prevalence was lower among women with a technical or trade certificate compared with those with no qualifications.

The two highest categories for "age left school" are the same as for "highest level of education", but the other categories provide better discrimination at the lower levels. There was a significant association between age left school and prevalence of multiple sclerosis, adjusted for age, for both men and women (table 2). For men, age adjusted prevalence increased with age left school $\left(\chi_{\text {trend }}^{2}=41\right.$, $1 \mathrm{df}, \mathrm{P}<0.0001)$. For women, age adjusted prevalence also tended to increase with age left school $\left(\chi_{\text {trend }}^{2}=241,1 \mathrm{df}, \mathrm{P}<0.0001\right)$, but the trend was not linear because of the very high rate in the "diploma" group.

Marital status was examined across the three levels of disability for men and women. Most people were married, $80 \%$ of men and $73 \%$ of women. The proportion of people who reported being divorced or separated increased with level of severity of disease from $6 \%$ to $18 \%$ in men and from $8 \%$ to $13 \%$ in women. After adjusting for age, an important potential confounder in this analysis, there was a significant association between level of severity and the probability of being divorced or separated. For men the estimated risk ratio (adjusted for age) for the moderate and severe disability groups compared with the low group were $1 \cdot 1$ (95\% confidence interval $(95 \%$ CI $0 \cdot 5-2 \cdot 2)$ and $4 \cdot 1(95 \%$ CI $2 \cdot 3-7 \cdot 3)$ respectively. For women the corresponding risk ratio estimates were $1.6(95 \% \mathrm{CI} 1 \cdot 1-2 \cdot 4)$ and $2.0(95 \% \mathrm{CI}$ $1 \cdot 3-3 \cdot 0)$. These results indicate that men in the severe disability group were four times more likely to be divorced or separated than men in the low disability group, and that women in the severe disability group were twice as likely to be divorced or separated as women with a low level of disability.

Employment status of men and women was also analysed. Overall, $50 \%$ of men and $27 \%$ of women reported being employed; $45 \%$ of men and $30 \%$ of women stated that they were

Table 1 Prevalence of MS by highest level of education

\begin{tabular}{|c|c|c|c|c|c|c|}
\hline \multirow[b]{2}{*}{$\begin{array}{l}\text { Highest level of } \\
\text { education }\end{array}$} & \multirow[b]{2}{*}{$n$} & \multirow{2}{*}{$\begin{array}{l}\text { Population } \\
\text { based on } \\
1981 \text { census }\end{array}$} & \multirow{2}{*}{$\begin{array}{l}\text { Crude } \\
\text { prevalence } \\
100000\end{array}$} & \multirow{2}{*}{$\begin{array}{l}\text { Age standard } \\
\text { prevalence } \\
100000\end{array}$} & \multicolumn{2}{|c|}{$\begin{array}{l}\text { Poisson regression model } \\
\text { (adjusted for age in 1981) }\end{array}$} \\
\hline & & & & & $\begin{array}{l}\text { Prevalence } \\
\text { ratio }\end{array}$ & $(95 \% C I)$ \\
\hline $\begin{array}{l}\text { Men } \geqslant 20 \text { y: } \\
\text { No qualifications } \\
\text { Trade or technical certificate } \\
\text { Diploma } \\
\text { University degree }\end{array}$ & $\begin{array}{r}364 \\
173 \\
45 \\
62\end{array}$ & $\begin{array}{r}1944731 \\
886620 \\
115651 \\
194747\end{array}$ & $\begin{array}{l}18 \cdot 7 \\
19 \cdot 5 \\
38 \cdot 9 \\
31 \cdot 8\end{array}$ & $\begin{array}{l}19 \cdot 0 \\
19 \cdot 6 \\
36 \cdot 9 \\
34 \cdot 8\end{array}$ & $\begin{array}{l}1 \cdot 00 \\
1 \cdot 03 \\
1 \cdot 94 \\
1 \cdot 76 \\
\chi^{2}=27 \cdot 8\end{array}$ & $\begin{array}{l}\text { (referent) } \\
(0 \cdot 86-1 \cdot 23) \\
(1 \cdot 42-2 \cdot 64) \\
(1 \cdot 34-2 \cdot 31) \\
P<0.001\end{array}$ \\
\hline $\begin{array}{l}\text { Women } \geqslant 20 \text { y: } \\
\text { No qualifications } \\
\text { Trade or technical certificate } \\
\text { Diploma } \\
\text { University degree }\end{array}$ & $\begin{array}{r}1177 \\
90 \\
243 \\
87\end{array}$ & $\begin{array}{r}2554769 \\
380107 \\
152628 \\
103418\end{array}$ & $\begin{array}{r}46 \cdot 1 \\
23 \cdot 7 \\
159 \cdot 2 \\
84 \cdot 1\end{array}$ & $\begin{array}{r}45 \cdot 8 \\
24 \cdot 8 \\
164 \cdot 1 \\
102 \cdot 2\end{array}$ & $\begin{array}{l}1 \cdot 00 \\
0.53 \\
3 \cdot 58 \\
1.99 \\
\chi^{2}=332,3\end{array}$ & $\begin{array}{l}\text { (referent) } \\
(0 \cdot 43-0 \cdot 66) \\
(3 \cdot 11-4 \cdot 12) \\
(1 \cdot 60-2 \cdot 49) \\
?<0 \cdot 0001\end{array}$ \\
\hline
\end{tabular}

Table 2 Prevalence of MS by age left school

\begin{tabular}{|c|c|c|c|c|c|c|}
\hline \multirow[b]{2}{*}{ Age left school } & \multirow[b]{2}{*}{$n$} & \multirow{2}{*}{$\begin{array}{l}\text { Population } \\
\text { based on } \\
1981 \text { census }\end{array}$} & \multirow{2}{*}{$\begin{array}{l}\text { Crude } \\
\text { prevalence } \\
100000\end{array}$} & \multirow{2}{*}{$\begin{array}{l}\text { Age standard } \\
\text { prevalence } \\
100000\end{array}$} & \multicolumn{2}{|c|}{$\begin{array}{l}\text { Poisson regression model } \\
\text { (adjusted for age in 1981) }\end{array}$} \\
\hline & & & & & $\begin{array}{l}\text { Prevalence } \\
\text { ratio }\end{array}$ & $(95 \% C I)$ \\
\hline $\begin{array}{l}\text { Men } \geqslant 20 y: \\
<15 \\
15 \\
16 \\
\geqslant 17 \\
\text { Diploma } \\
\text { University degree }\end{array}$ & $\begin{array}{r}157 \\
177 \\
122 \\
79 \\
45 \\
62\end{array}$ & $\begin{array}{l}915856 \\
883596 \\
643792 \\
469552 \\
115651 \\
194747\end{array}$ & $\begin{array}{l}17 \cdot 1 \\
29 \cdot 0 \\
19 \cdot 0 \\
16 \cdot 8 \\
38 \cdot 9 \\
31 \cdot 8\end{array}$ & $\begin{array}{l}15 \cdot 0 \\
19 \cdot 0 \\
21 \cdot 5 \\
27 \cdot 3 \\
37 \cdot 0 \\
34 \cdot 7\end{array}$ & $\begin{array}{l}1 \cdot 00 \\
1 \cdot 32 \\
1 \cdot 44 \\
1 \cdot 63 \\
2 \cdot 50 \\
2 \cdot 31 \\
\chi^{2}=44 \cdot 3\end{array}$ & $\begin{array}{l}\text { (referent) } \\
(1 \cdot 05-1 \cdot 65) \\
(1 \cdot 13-1 \cdot 84) \\
(1 \cdot 23-2 \cdot 17) \\
(1 \cdot 79-3 \cdot 49) \\
(1 \cdot 70-3 \cdot 12) \\
P<0.001\end{array}$ \\
\hline $\begin{array}{l}\text { Women } \geqslant 20 y: \\
<15 \\
15 \\
16 \\
\geqslant 17 \\
\text { Diploma } \\
\text { University degree }\end{array}$ & $\begin{array}{r}356 \\
444 \\
278 \\
178 \\
243 \\
87\end{array}$ & $\begin{array}{r}945163 \\
1032566 \\
687603 \\
381316 \\
152628 \\
103418\end{array}$ & $\begin{array}{r}37 \cdot 7 \\
43 \cdot 0 \\
40 \cdot 4 \\
46 \cdot 7 \\
159 \cdot 2 \\
84 \cdot 1\end{array}$ & $\begin{array}{r}36 \cdot 6 \\
41 \cdot 0 \\
42 \cdot 3 \\
66 \cdot 8 \\
164 \cdot 2 \\
102 \cdot 6\end{array}$ & $\begin{array}{l}1 \cdot 00 \\
1 \cdot 19 \\
1 \cdot 25 \\
1 \cdot 72 \\
4 \cdot 83 \\
2 \cdot 72 \\
\chi^{2}=339\end{array}$ & $\begin{array}{l}\text { (referent) } \\
(1.03-1.37) \\
(1.06-1.47) \\
(1 \cdot 42-2 \cdot 07) \\
(4 \cdot 07-5.72) \\
(2 \cdot 13-3.46) \\
P<0.001\end{array}$ \\
\hline
\end{tabular}


retired or receiving a pension. For men, $78 \%$ in the low disability group were employed compared with $27 \%$ in the moderate group and just $4 \%$ in the severe group. The corresponding figures for women were $40 \%, 8 \%$, and $1 \%$. After adjusting for age, there was a significant association between level of severity and the probability of not being employed. Estimates from the age adjusted risk ratio models for the moderate and severe groups relative to the low group were 2.7 (95\% CI $2 \cdot 1-3 \cdot 6)$ and $17 \cdot 6(95 \%$ CI $7 \cdot 5-41 \cdot 4)$ respectively for men and 4.0 (95\% CI $2 \cdot 7-5 \cdot 8)$ and $24.6(95 \%$ CI $8 \cdot 0-76 \cdot 1)$ respectively for women. Trade and farm workers were less likely to be in paid employment than professional or clerical workers as their level of disability increased.

\section{Discussion}

There have been few studies of the relation between socioeconomic variables and the prevalence of multiple sclerosis and none has previously been undertaken in Australia. It is the largest of such studies in terms of case numbers so far reported with the exception of that based on the United States veteran series from the second world war ${ }^{11}$ which analysed 5305 veterans with multiple sclerosis. Our study has shown that there is a significantly higher frequency of multiple sclerosis in patients who leave school at an older age and achieve a higher educational level. This contrasts with a finding in the United States of Lauer ${ }^{11}$ in which there was no significant association with level of education, although multivariate analyses did identify an association with socio-economic factors that were indicators of higher affluence such as better nutrition, higher meat consumption, and higher sanitary level. Visscher and coworkers ${ }^{12}$ found a higher level of education in patients with multiple sclerosis than the general population of California. A significantly higher than expected proportion of patients with multiple sclerosis in professional, technical, and administrative occupational groups at disease onset than those in other categories of employment was found in the United Kingdom, ${ }^{1-3}$ but not in some studies from the United States, Spain, and Israel. ${ }^{4-6}$ However, in one study from the United States ${ }^{13}$ there was an association with higher educational levels, and in Germany a predominance of women in commercial and administrative fields of employment was noted. ${ }^{14}$

The finding of a greater prevalence of multiple sclerosis in people of higher socioeconomic status in Australia is unlikely to be due to selection bias in the study, as it is based on a point prevalence survey of the whole population in which there was a high level of case ascertainment. $^{7-8}$ It is also unlikely to be related to differences in access to medical services as there is a universal healthcare system. Others have speculated about the reasons for the association without arriving at definite conclusions. ${ }^{11-15}$ Poskanzer and colleagues ${ }^{16}$ postulated that there was a close similarity between multiple sclerosis and poliomyelitis; early exposure to infection, because of poorer standards of hygiene in those of lower socioeconomic status may result in relative immunity to a virus infection that triggers disease in later life. Acheson ${ }^{15}$ has argued against this hypothesis for the epidemiological pattern of the disease. Although there are no major differences in the standards of hygiene in the Australian community (except for the Aboriginal population, who are not affected by the disease) it does seem to be the most plausible explanation. The possibility of common genetic factors linking intelligence and personality traits with susceptibility to multiple sclerosis cannot be excluded.

The finding of a greater level of divorce and separation and lower rates of participation in the paid workforce in more disabled patients is consistent with other studies. ${ }^{617}$ It highlights the need to consider the social issues related to multiple sclerosis and other disabling diseases.

1 Miller H, Ridley A, Shapira K. Multiple sclerosis. A note on social incidence. $B M \mathcal{F}$ 1960;2:343-5.

2 Russell WR. Multiple sclerosis: occupational and socia group at onset. Lancet 1971;2:832-4.

3 Phadke JG, Downie AW. Epidemiology of multiple sclerosis in the north-east (Grampian region) of Scotland-an update. $\mathcal{F}$ Epidemiol Community Health 1987;41:5-13.

4 Antonovsky A, Leibowitz U, Smith HA, Medalie JM, Balogh M, Kats R, et al. Epidemiologic study of multiple sclerosis in Israel. Arch Neurol 1965;13:183-93.

5 Alter M, Spier J. Clinical evaluation of possible etiologic factors in multiple sclerosis. Neurology 1968;18:109-16.

6 Cervera-Deval J, Moran-Guillen MP, Fenollosa-Vasquez $P$, Serra-Escorihuela M, Vilchez-Padilla J, Burguera J. Social handicaps of multiple sclerosis and their relation Social handicaps of multiple sclerosis and their relation
to neurological alterations. Arch Phys Med Rehabil 1994; to neurological

7 Hammond SR, McLeod JG, Millingen KS, Stewart-Wynne EG, English D, Holland JT, McCall MG. The epidemiology of multiple sclerosis in three Australian cities: Perth, Newcastle, and Hobart. Brain 1988;111:1-25.

8 McLeod JG, Hammond SR, Hallpike JF. Epidemiology of multiple sclerosis in Australia. With NSW and SA survey results. Med F A ust 1994;160:117-22.

9 Armitage P, Berry G. Statistical methods in medical research, 3rd ed. Oxford: Blackwell, 1994.

10 Wacholder S. Binomial regression in GLIM: estimating risk ratios and risk differences. Am $\mathcal{F}$ Epidemiol, 1986;123: 174-9.

11 Lauer $\mathrm{K}$. The risk of multiple sclerosis in the USA in relation to socio-geographic features: a factor-analytic study. $\mathcal{f}$ Clin Epidemiol 1994;47:43-8.

12 Visscher BR, Clark VA, Detels R, Malmgren RM Valdiviczo NL, Dudley JP. Two populations of multiple sclerosis. Clinical and demographic characteristics. $f$ Neurol 1981;225:237-49.

13 Beebe GW, Kurtzke JF, Kurland LT, Auth TZ, Nagler B. Studies on the natural history of multiple sclerosis. 3 . Epidemiologic analysis of the Army experience in World War II. Neurology 1967;17:1-17.

14 Lauer K, Firnhaber W. Epidemiological investigations into multiple sclerosis in Southern Hesse III. The possible influence of occupation on the risk of disease. Acta Neurol Scand 1985;72:397-402.

15 Acheson ED. The epidemiology of multiple sclerosis. In: Matthews WB, Acheson ED, Batchelor JR, Weller RO, eds. McAlpine's multiple sclerosis. Edinburgh: Churchill eds. McAlpine's multiple

16 Poskanzer DC, Schapira K, Miller H. Multiple sclerosis and poliomyelitis. Lancet 1963;2:917-21.

17 Bauer HJ, Hanefeld FA. Multiple sclerosis. Its impact from childhood to old age. London: WB Saunders, 1993:177. 